\title{
ПЛАН ГОЭЛРО КАК ФАКТОР ТРАНСФОРМАЦИИ ПРОСТРАНСТВА ПОВОЛЖСКОГО ГОРОДА
}

\author{
(c) 2020 Е.Ю. Семенова
}

Самарский федеральный исследовательский центр РАН, Самарский государственный технический университет

Статья поступила в редакцию 02.12.2020

\begin{abstract}
В статье исследуется возможность изменения городского пространства в связи с перспективами реализации плана ГОЭЛРО. Выявлены составляющие плана ГОЭЛРО в отношении поволжских городов, предполагающие изменения в сфере коммуникаций, застройки. Сопоставлено влияние плана на перспективы развития городского пространства в поволжских городах.

Ключевые слова: ГОЭЛРО, Поволжье, городское пространство.

DOI: $10.37313 / 2658-4816-2020-2-4-93-101$

Исследование выполнено при финансовой поддержке

Фонда «История Отечества» в рамках выставочного проекта

«Люди света: российский ответ на вызовы технологических революций ХХ века».

Передвижная выставка к 100-летию плана ГОЭЛРО

(договор № 9/2020/ФП-В от 07.05.2020 г.).
\end{abstract}

План ГОЭЛРО (государственный план электрификации Советской России) получил широкое освещение, привлекая внимание исследователей как определенная программа развития народного хозяйства ${ }^{1}$ в контексте индустриализации Советского государства в период 1920-х - 1930-х гг. ${ }^{2}$, в ключе дискурсов о сущности и перспективах ГОЭЛРО ${ }^{3}$, в проблематике строительства отдельных объектов энергетики ${ }^{4}$.

В региональном ракурсе в изучении истории социально-экономической повседневности обращение к идеям, изложенным в плане ГОЭЛРО, осуществлялось рядом авторов в связи с процессом ин-

Семенова Екатерина Юрьевна, доктор исторических наук, доцент, старший научный сотрудник отдела истории и археологии СамНЦ РАН, профессор кафедры философии и социально-гуманитарных наук Самарского государственного технического университета.

E-mail:dashka129k@yandex.ru дустриализации ${ }^{5}$, другие исследователи, разносторонне изучавшие повседневность данной эпохи, не уделяли внимание плану ГОЭЛРО 6 .

В данной статье внимание автора обращено к плану ГОЭЛРО как программе перспективного развития пространства поволжского города. Понятие «регион» не употребляется целенаправленно, поскольку допустимо для характеристики только определенной территории, включающей Нижнее и Среднее Поволжье. Поволжский город рассматривается в соотнесении с волжской акваторией. В данном ключе нас будут интересовать волжские города, включенные в плане ГОЭЛРО в Приволжский район (Симбирск, Астрахань, Самара, Казань, Саратов и другие), а также в Центрально-Промышленный район (Ярославль, Кострома, Нижний Новгород и другие). Поскольку реализация плана ГОЭЛРО 
осуществлялась преимущественно в условиях первых пятилеток, затянулась, обратим внимание на то, что названия ряда городов за данный период изменились (например, Царицын с 1925 г. был переименован в Сталинград, Нижний Новгород - с 1932 г. в Горький, Самара с 1935 г. стала носить название Куйбышев).

В отношении Центрально-Промышленного района план предполагал создание ряда объектов, необходимых для перспектив уже имеющегося производства и формирования нового. Отметим, что Ярославль снабжался электричеством благодаря Центральной электрической станции трамвая и электрического освещения (общая установленная мощность - 3200 кВт), которая находилась в трех километрах от железнодорожной станции Ярославль-город. Однако дальнейшее существование города на ее мощностях не предполагало развития, поскольку проблематично было использовать дрова и торф для обеспечения объекта, находящегося в центре города, невозможно было увеличивать мощности за счет воды, так как станция находилась на возвышенности и далеко от речного русла ${ }^{7}$. Кострома являлась центром льняной промышленности и при этом не имела пригодных электрических станций ${ }^{8}$. В Нижнем Новгороде находились три более крупные электрические станции, в том числе неработающая паровая (на 800 кВт), Канавинская станция однофазного и постоянного тока (на 2010 кВт) и водопроводно-электрическая (на 3800 л.с.), для обеспечения работы которых требовалось жидкое топливо (для дизелей), а также электрические станции промышленных предприятий, которые не могли обеспечить даже собственные мастерские. При этом в Нижнем Новгороде были расположены крупные промышленные объекты - Сормовский завод, гвоздильно-болтовый завод «Новая Этна» и другие 9 . Подчеркнем, что из всех имеющихся источников энергетики только Центральная электростанция трамвая и электрического освещения в Ярославле предполагалась для использования усиленного электроснабжения в ЦентральноПромышленном районе ${ }^{10}$.

Согласно плану ГОЭЛРО в Центрально-Промышленном районе на месторождениях торфа должны были базироваться Ярославская станция (до 40 тыс. кВт) и районная станция рядом с Балахной (до 100 тыс. кВт). От Ярославской электростанции предполагалось протянуть воздушные линии до волжских городов Костромы, Рыбинска, Нерехты (что сопровождалось бы снабжением электричеством не только данных городов, но и прилегающего право- и левобережья), а от балахнинской - воздушные линии до Нижнего Новгорода и Козьмодемьянска (что подпитывало бы железную дорогу и содействовало развитию лесопильных, деревообделочных и перерабатывающих сплавной лес предприятий). Также предполагалась возможность строительства временной электрической станции на Волге в районе устья реки Костромы с обеспечением ее ресурсами торфа и древесины ${ }^{11}$.

Большую часть энергетики в Приволжском районе из волжских городов обеспечивали Казань, Самара, Сызрань, Вольск, Саратов, Балашов, Царицын, Астрахань, преимущественно за счет промышленных объектов ${ }^{12}$. В Самаре к дальнейшему использованию предполагались Самарская электрическая городская станция (обслуживала городскую распределительную сеть и трамвай), станция Самарского трубочного завода и Самарского зернохранилища Государственного банка, объединение которых позволяло увеличить свободную суммарную мощность, увеличить количество потребителей и электрифицировать ряд мелких предприятий с собственными силовыми установками ${ }^{13}$. Для нужд Вольска рассматривалась возможность соединения электропередачами станции четырех цементных заводов, располагавшихся недалеко от города, в Царицыне - объединение городской 
станции и установок располагавшихся в нескольких километрах от города оружейного завода и Максимовского лесопромышленного товарищества, в Саратове - использование городской станции бывшего Бельгийского общества (оборудована генераторами постоянного тока, работала в условиях перегрузки), в Астрахани - объединение установок городской электрической станции, холодильников - Астраханского и Унион, станции астраханского трамвая (бывшего Анонимного общества рельсовых путей) при введении новых турбогенераторов и работе по городской сети ${ }^{14}$. Электрическая станция 1896 г. в Казани была полностью загружена и уже не принимала новых потребителей, можно было рассчитывать только на установки порохового завода (при условии одновременной работы дизельной и паротурбинной станций после починки одного из турбогенераторов), чего бы хватило для снабжения электричеством казанского трамвая, Алафузовской фабрики и города ${ }^{15}$.

Приволжский район рассматривался в новой программе как территория развития металлодобывающей и металлообрабатывающей промышленности, в частности, и тяжелой индустрии в целом ${ }^{16}$. План включал расширение металлургического производства в Царицыне на основе формирования металлургического центра с доменной выплавкой чугуна из уральских руд на донецком коксе и дальнейшее развитие предприятий по производству изделий из металла. Планировалось, что металлургические предприятия Царицына будут выпускать до 25 млн пудов продукции, на что потребуется дополнительно 10 тыс. кВт энергии. Также предполагалось развитие металлообрабатывающей промышленности в Казани, Самаре и Саратове ${ }^{17}$. Было необходимо также поддерживать потребности имеющегося производства, включая работу четырех крупных цементных заводов в Вольске, крупных заводов «Новая Этна» и «Стелла» в Саратове, мукомольного производства в Самаре и т.д. ${ }^{18}$

В отношении Приволжского района отмечалось, что базой электрификации могут быть только залежи топлива, a на «гидравлические силы» «рассчитывать не приходится». Предполагалось использовать районные станции в сельской местности (у села Ундоры, у Кашпира (в ГОЭЛРО называется Кашпуром), у Алтаты и в Царицынском районе) ${ }^{19}$. Возможность в будущем постройки электростанции предполагалась только в отношении снабжения Симбирска, на реке Свияге ${ }^{20}$. В Астрахани допускалась возможность создания станции, работающей на газе или нефтяном топливе, которая обслуживала бы только саму Астрахань (освещение, трамвай и работу имеющихся предприятий) и ближайшие окрестности ${ }^{21}$. В планах электрификации особая роль уделялась Царицыну, который должен был стать центром пересечения линий электрификации в направлении Донецкого бассейна. Через Астрахань предполагалось вести второочередную линию от одного из черноморских портов ${ }^{22}$. Линией электропередачи следовало соединить Казань и Саратов, Кашпир и Самару, Новоузенск и Саратов, Черный Яр и Царицын ${ }^{23}$.

В ходе реализации программы ГОЭЛРО (план ГОЭЛРО был принят на VIII Всероссийском съезде Советов 22 декабря 1920 года) при оснащении электрификацией поволжских городов в 1920-1930-е гг. были созданы следующие объекты (смотрите таблицу 1).

В дальнейшем в ходе накопления данных, прогнозирования и планирования при формировании перспективных планов развития экономики всей страны и ее отдельных отраслей, обобщения полученных данных председателем Государственной плановой комиссии при Совете Труда и Обороны СССР Г.М. Кржижановским в докладе на пленарном заседании президиума Госплана 23 июня 1925 г., при подготовке специальной комиссией в 
Таблица 1. Объекты электрификации, введенные согласно плану ГОЭЛРО 1920 г., позволившие обеспечить электричеством волжские города ${ }^{24}$

\begin{tabular}{|c|c|c|}
\hline $\begin{array}{c}\text { Дата ввода в } \\
\text { эксплуатацию } \\
\text { (торжественный } \\
\text { пуск) }\end{array}$ & Объект, территория ${ }^{25}$ & $\begin{array}{c}\text { Электрифицированный } \\
\text { район }\end{array}$ \\
\hline 6 сентября 1925 г. & $\begin{array}{l}\text { Нижегородская (Горьковская, имени } \\
\text { А.В. Винтера) районная } \\
\text { электростанция (первоначально - } \\
\text { государственная районная } \\
\text { электростанция в городе Балахна), в } \\
1933 \text { г. стала самой крупной в СССР, } \\
\text { Нижегородская губерния (с } 1929 \text { г. - } \\
\text { Нижегородская область, затем - } \\
\text { Нижегородский край, с } 1932 \text { г. - } \\
\text { Горьковский край, с } 1936 \text { г. - } \\
\text { Горьковская область) }\end{array}$ & $\begin{array}{l}\text { Нижний Новгород } \\
\text { (включая предприятия, в } \\
\text { т.ч. Сормовский завод) и } \\
\text { прилегающая территория } \\
\text { города (с } 1919 \text { г.) Канавино }\end{array}$ \\
\hline 21 ноября 1926 г. & $\begin{array}{l}\text { Ярославская (Ляпинская) районная } \\
\text { электростанция, с } 1932 \text { г. - } \\
\text { Ярославская ГРЭС, введена на полную } \\
\text { мощность, Ярославль, Ярославская } \\
\text { губерния (с } 1929 \text { г. в составе } \\
\text { Ивановской Промышленной области, с } \\
1936 \text { г. - Ярославская область) }\end{array}$ & $\begin{array}{l}\text { Снабжение } \\
\text { электричеством Ярославля, } \\
\text { Рыбинска, Ростова, } \\
\text { Костромы, } \\
\text { централизованное } \\
\text { теплоснабжение в } \\
\text { Ярославле }\end{array}$ \\
\hline
\end{tabular}

июне 1926 г. доклада «Общие предпосылки к генеральному плану реконструкции народного хозяйства на энергетической базе на ближайшие 10-15 лет» первоначальные основы ГОЭЛро были скорректированы ${ }^{26}$.

Кроме первоначально планируемых согласно ГОЭЛРО 1920 г. объектов, в городах Поволжья в 1920-1930-е гг. появились ряд ТЭЦ, ГЭС и линий электропередачи, созданных вне плана, на основе инициативы местных властей (смотрите таблицу 2). Часть из них была включена в план ГОЭЛРО позже 1920 г. отдельной строкой, как Сызранская ГЭС (смотрите таблицу 2). Так, по инициативе сызранского уездного исполкома, заручившегося содействием Г.М. Кржижановского, в план Электростроя ГОЭЛРО включили новый объект - Сызранскую гидроэлектростанцию на реке Сызранке ${ }^{27}$; по инициативе XXII Сталинградской городской партконференции (декабрь 1926 г.) было принято решение о строительстве Сталинградской (Волгоградской) ГРЭС 28 ; Пленум Костромского Губкома партии, рассматривая план капитального строительства в губернии (1927 г.), принял резолюцию о необходимости постройки в Костроме Центральной электрической станции (ЦЭС, затем Костромской ТЭЦ-1 $)^{29}$. В первооснове создания части объектов лежали государственные директивы, как при строительстве Угличской и Рыбинской ГЭС, возведенных согласно Постановлению СНК СССР и ЦК ВКП(б) от 14 сентября 1935 за № 2074 «О строительстве гидроузла в районе Углича и Рыбинска» 30 , или ГЭС Куйбышевского гидроузла, более поздней стройки, основы которой заложило совместное Постановление СНК СССР и ЦК ВКП(б) № 1339 «О строительстве Куйбышевского гидроузла на реке Волге и гидроузлов на реке Каме» от 10 августа 1937 г. ${ }^{31}$

Исследователи подчеркивают, что не все предполагаемые в государственном плане 
Таблица 2. Объекты электрификации, введенные вне плана ГОЭЛРО 1920 г. в 1920-1941-е гг., позволившие обеспечить электричеством волжские города ${ }^{32}$

\begin{tabular}{|c|c|c|}
\hline $\begin{array}{c}\text { Дата ввода } \\
\text { в эксплуатацию } \\
\text { (торжественный пуск) }\end{array}$ & Объект, территория & $\begin{array}{c}\text { Электрифицированный } \\
\text { район }\end{array}$ \\
\hline 7 ноября 1929 г. & $\begin{array}{l}\text { Сызранская ГЭС, Сызрань, Средневолжская } \\
\text { область (с } 1929 \text { г. - Средневолжский край, с } \\
1935 \text { г. - Куйбышевский край, с } 1936 \text { г. - } \\
\text { Куйбышевская область, с } 1992 \text { г. - } \\
\text { Куйбышевская область) }\end{array}$ & Город Сызрань \\
\hline 1 мая 1930 г. & $\begin{array}{l}\text { Саратовская ГРЭС, Саратов, } \\
\text { Нижневолжский край (с } 1928 \text { г., с } 1934 \text { г. - } \\
\text { Саратовский край, с } 1936 \text { г. - Саратовская } \\
\text { область) }\end{array}$ & Саратов \\
\hline 8 ноября 1930 г. & $\begin{array}{l}\text { Сталинградская (Волгоградская) ГРЭС, } \\
\text { Сталинград (с } 1961 \text { г. - Волгоград), } \\
\text { Нижневолжский край (с } 1928 \text { г., с } 1934 \text { г. - } \\
\text { Сталинградский край, с } 1936 \text { г. - } \\
\text { Сталинградская область, с } 1961 \text { г. - } \\
\text { Волгоградская область) }\end{array}$ & Сталинград (Царицын) \\
\hline 1923 г. & $\begin{array}{l}\text { Линия электропередачи Москва - Нижний } \\
\text { Новгород }\end{array}$ & Москва - Нижний Новгород \\
\hline 16 сентября 1930 г. & $\begin{array}{l}\text { Костромская ТЭЦ-1, Кострома, в составе } \\
\text { Ивановской Промышленной области (с } \\
1944 \text { г. - Костромской области) }\end{array}$ & $\begin{array}{l}\text { Тепловая и электроэнергия и } \\
\text { холодная вода для } \\
\text { предприятий Костромы }\end{array}$ \\
\hline 1931 г. & $\begin{array}{l}\text { ТЭЦ Горьковского автозавода, Нижний } \\
\text { Новгород (Горький), Нижегородский край } \\
\text { (с } 1932 \text { г. - Горьковский край, с } 1936 \text { г. - } \\
\text { Горьковская область) }\end{array}$ & \\
\hline 15 января 1933 г. & $\begin{array}{l}\text { Казанская ГРЭС (Казанская ТЭЦ-1), Казань, } \\
\text { Автономная Татарская ССР (с } 1936 \text { г. - } \\
\text { Татарская АССР, с } 1990 \text { г. - Татарская ССР, } \\
\text { с } 1992 \text { г. - Республика Татарстан) }\end{array}$ & $\begin{array}{l}\text { Часть города Казань, рабочие } \\
\text { поселки рядом с Казанью }\end{array}$ \\
\hline 1 ноября 1933 г. & $\begin{array}{l}\text { Самарская теплотрасса, первая в } \\
\text { Поволжье, Самара (с } 1935 \text { г. - Куйбышев, с } \\
1991 \text { г. - Самара), Средневолжская область } \\
\text { (с } 1929 \text { г. - Средневолжский край, с } \\
1935 \text { г. - Куйбышевский край, с } 1936 \text { г. - } \\
\text { Куйбышевская область, с } 1992 \text { г. - } \\
\text { Самарская область) }\end{array}$ & $\begin{array}{l}\text { Отопление зданий в городе } \\
\text { Самара }\end{array}$ \\
\hline 21 декабря 1933 г. & $\begin{array}{l}\text { Кашпирская ТЭС, Средневолжская область } \\
\text { (с } 1929 \text { г. - Средневолжский край, с } 1935 \text { г. } \\
\text { - Куйбышевский край, с } 1936 \text { г. - } \\
\text { Куйбышевская область, с } 1992 \text { г. - } \\
\text { Куйбышевская область) }\end{array}$ & Часть города Сызрань \\
\hline 4 июля 1934 г. & $\begin{array}{l}\text { Ярославская ТЭЦ-1, Ярославль, в составе } \\
\text { Ивановской Промышленной области (с } \\
1936 \text { г. - Ярославская область) }\end{array}$ & $\begin{array}{l}\text { Ярославский шинный завод, } \\
\text { начало первой } \\
\text { теплоэлектроцентрали в } \\
\text { Ярославле }\end{array}$ \\
\hline 5 ноября 1934 г. & $\begin{array}{l}\text { Саратовская ТЭЦ-1, Саратов, Саратовский } \\
\text { край (с } 1936 \text { г. - Саратовская область) }\end{array}$ & Часть Саратова \\
\hline Январь 1938 г. & $\begin{array}{l}\text { Казанская ТЭЦ-2, Казань, Татарская АССР } \\
\text { (с } 1990 \text { г. - Татарская ССР, с } 1992 \text { г. - } \\
\text { Республика Татарстан) }\end{array}$ & Казань \\
\hline 8 декабря 1940 г. & $\begin{array}{l}\text { Угличская ГЭС на реке Волге, Углич, } \\
\text { Ярославская область }\end{array}$ & Углич - Москва \\
\hline 1940 г. & $\begin{array}{l}\text { Линия электропередачи } 220 \text { кВ Углич- } \\
\text { Москва }\end{array}$ & Углич - Москва \\
\hline 15 октября 1941 г. & $\begin{array}{l}\text { Безымянская ТЭЦ, Куйбышев (с } 1991 \text { г. - } \\
\text { Самара), Куйбышевская область (с } 1992 \text { г. - } \\
\text { Самарская область) }\end{array}$ & $\begin{array}{l}\text { Электро- и теплоснабжение } \\
\text { эвакуированных } \\
\text { предприятий Куйбышева }\end{array}$ \\
\hline 18 ноября 1941 г. & $\begin{array}{l}\text { Рыбинская ГЭС на реке Волге, Рыбинск, } \\
\text { Ярославская область }\end{array}$ & Рыбинск - Москва \\
\hline
\end{tabular}


электрификации Советской России идеи были реализованы ${ }^{33}$.

Одним из последствий реализации плана ГОЭЛРО в волжских городах стали изменения в городском пространстве, отличавшиеся неоднозначностью.

Отметим, что план был прежде всего ориентирован на развитие промышленного производства (неслучайно он был реализован преимущественно в условиях программы форсированной индустриализации). Поскольку часть объектов энергетики требовала оснащения, а также возводилась с целью обеспечения электричеством будущего фабрично-заводского производства, планируемого на данной территории, в пределах города и пригородной зоны создавались промышленные предприятия. Так, в Угличе на базе ремонтных мастерских, обслуживающих строительство Угличской ГЭС, был образован самостоятельный ремонтно-механический завод, на котором ремонтировалась тяжелая техника, выпускались различные механизмы, облегчающие строительство.

ГОЭЛРО не только косвенно прогнозировал изменения в городском пространстве, не связанные с промышленными объектами. В нем прямо обращалось внимание на нормативную мощность электрификации городов - 40 ватт на жителя, предполагая благоустройство территории уличным освещением, водопроводом, в крупных городах (Нижнем Новгороде, Казани, Самаре, Саратове, Царицыне, Астрахани) - трамвайным сообщением (а также его активное развитие) и другими удобствами ${ }^{34}$.

Наличие трамвайного сообщения, для которого необходимо электропитание, рассматривалось в ряде дореволюционных справочников по городу в качестве достопримечательности ${ }^{35}$. В одном из них сообщалось: «Саратов имеет 5 газет, телефонную сеть, электрическое освещение, трамвай, великолепные мостовые, много ученых, просветительных и культурных обществ, университет, консерваторию, В.Ж. курсы..., двадцать средних и массу низших учебных заведений..., прекрасный парк «Липки», два музея, три театра, множество кинематографов и проч.» ${ }^{36}$, то есть трамвай указывался в числе первых значимых объектов.

В 1930-е гг. по мере развития электрификации трамвайное сообщение расширилось в Сталинграде (Царицыне), Саратове, Астрахани, Самаре, Казани и других краевых и областных центрах, трамвайные линии заняли больше городской территории (хотя в его развитии продолжали оставаться проблемы, оно оставалось недостаточно развитым в городах, не имевших такого значения $)^{37}$. Например, в Казани в 1930-е гг. были открыты два новых маршрута (№ 5 и № 6 до Суконной слободы и от Ершова поля до меховых фабрик), в Самаре за 1927-1930-е гг. - четыре маршрута (№ 6, № 7, № 8, № 9) ${ }^{38}$.

Другой развивающейся сетью, а для части населенных пунктов - новацией, стало электрическое освещение. Например, в Саратовской губернии в Хвалынске в дореволюционный период улицы освещались керосиновыми фонарями, в Балашове электрическое освещение стало внедряться только в начале Первой мировой войны ${ }^{39}$. Отметим, что не все волжские города в условиях реализации плана ГОЭЛРО, учитывая его доработки, динамично оснащались электрическим освещением. Например, в Городце (Нижегородская губерния, затем - Нижегородский край, Горьковский край, Горьковская область) к концу 1920-х гг. не все улицы, жилые дома, школы были электрифицированы, применялось освещение на основе керосина ${ }^{40}$.

Развитие водопровода и канализации в крупных волжских городах осуществлялось еще в дореволюционный период, в том числе в условиях Первой мировой войны ${ }^{41}$. При реализации плана ГОЭЛРО сеть водопровода и канализации росла. Например, в Саратове после открытия Саратовской ГРЭС работа водопровода обеспечивалась впервые на основе электрической насосной станции, и к концу 1930-х гг. водопроводная сеть выросла почти вдвое (с 1917 г.), а к канализации была 
подключена треть всех домовладений ${ }^{42}$. В Казани и Астрахани водопровод действовал с XIX в. (в Казани - с 1874 г., в Астрахани с 1880 г.), однако канализация была создана только в условиях электрификации: в Казани - в 1928 г., в Астрахани - в 1934 г.

Развитие архитектурных стилей в советском городе в период реализации плана электрификации позволяло строить большие здания, поскольку осуществлялась их теплофикация в связи с ростом мощностей ГРЭС и их формированием. Так, в Самаре (Куйбышеве) в конце 1920-х - 1930-е гг. были построены монументальные здания в стиле конструктивизма (Дом промышленности, Клуб им. Ф.Э. Дзержинского, Дом специалистов, Телеграф, Клуб Красной Армии им. К.Е. Ворошилова и другие) и в стиле сталинского ампира (Дворец культуры им. В.В. Куйбышева и другие) ${ }^{43}$, а в 1933 г. стала реализовываться работа по теплофикации города от Самарской ГРЭС ${ }^{44}$.

Отметим, что план электрификации вносил проблемы в трансформацию городского пространства. В процессе реализации плана электрификации на некоторое время часть города превратилась в зону работ и раскопок. Так, в Казани в 1925-1927 гг. Электротрест вел работы по капитальному улучшению электрификации города, в связи с чем осуществлялся переход сети с постоянного тока на трехфазный переменный путем прокладки подземного кабеля, и в результате улицы были изрыты канавами ${ }^{45}$.

Наиболее печальным последствием электрификации для городского сектора стало его исчезновение. При строительстве объектов энергетики часть городского пространства была затоплена, как это произошло с волжским городом Мологой, входившим ранее в состав Ярославской губернии, а позже с исторической частью города Ставрополя (с 1964 г. - Тольятти), являвшегося частью Куйбышевской области (в дореволюционный период - Самарской губернии).

Таким образом, план электрификации являлся важной составляющей, определившей изменение городского пространства
СССР во второй половине 1920-х -1930-е гг. Закладывая основу промышленного развития, он параллельно стал базой развития коммуникаций, транспорта, градостроительства. Данный процесс сопровождался трансформациями территории города как в отношении привычного ранее облика, так и в аспекте удобств, включая повышение комфорта, временные неудобства, в нескольких случаях (в более поздний период) - утрату города.

\section{ПРИМЕЧАНИЯ}

${ }^{1}$ Акимова Г.З., Чижов С.Ф., Чижова Е.Н. Технология плана ГОЭЛРО как портфеля проектов // Вестник БГТУ им. В.Г. Шухова. 2018. № 10. С. 250-259; Антоненко С. План ГОЭЛРО: образ опережающей модернизации // Родина. 2011. № 1. С. 2-4 и др.

${ }^{2}$ Воейков Е.B. Топливное обеспечение индустриального развития Поволжского региона в плане ГОЭЛРО // Известия Самарского научного центра РАН. Самара, 2018. Т. 20. № 3. С. 78-83; Чолахян В.А. Индустриальная модернизация Саратовского края в годы второй пятилетки (19331937 годы) // Известия Саратовского университета. Сер. История. Международные отношения. 2011. Т. 11. Вып. 2. Ч. 2. С. 114-121 и др.

${ }^{3}$ Советский проект. 1917-1930-е гг.: этапы и механизмы реализации: сб. науч. тр. / Под ред. О.В. Горбачева и Л.Н. Мазур. Екатеринбург: Изд-во Урал. ун-та, 2018. 558 с. и др.

${ }^{4}$ Большая Волга. Из истории строительства Верхневолжских ГЭС / Авт.-сост. А.А. Голицын. Рыбинск: Медиарост, 2015. 164 с.; Бурдин E.A. Волжский каскад ГЭС: триумф и трагедия России. М.: РОССПЭН, 2011. 398 с.; Малышева $H$. Угличской ГЭС - 80 лет // Угличская газета. 2020. 7 декабря [Электронный ресурс]. URL: https://gazetauglich.ru/news/1298-uglichskojges-80-let\# (дата обращения: 08.12.2020); Hoскова О.Л., Розенберг Г.С. История создания Куйбышевского водохранилища // Известия Самарского научного центра Российской академии наук. 2012. Т. 14. № 1. С. 222-226; Сuницын М.O. Очерки истории Нижегородской районной электростанции. Н. Новгород: [б.и.], 2020. 316 c. URL: https://vk.com/doc156425353 443506631?hash=3dc92bedef35a2b76e (дата обращения: 10.11.2020); Халиулин P.P. Развитие генерирующих мощностей электросетевого хозяйства. Первенец энергетики Татарстана // 
Энергетика Татарстана. 2006. № 4. С. 52-56.

${ }_{5}^{5}$ Чолахян B.A. Жилищные условия и благоустроенность городов Нижнего Поволжья в 1920-1930-х годах // Известия Саратовского университета. Сер. История. Международные отношения. 2009. Т. 9. Вып. 2. С. 64-73.

${ }^{6}$ Климочкина А.Ю. Повседневная жизнь российского провинциального города 1930-х гг. (на материалах Среднего Поволжья): автореф. дис. ... канд. ист. наук. Самара, 2009. 21 с.; Соловьева T.A. Социально-экономические аспекты городской повседневности Саратова в 1920-е гг. // Клио. 2013. № 11 (83). С. 79-83; Сальникова A.А. Советская власть и культурный ландшафт провинциального города (Казань, 1920-1930 гг.) // Россия и современный мир. 2004. № 1(42). С. $160-180$ и др.

${ }^{7}$ План ГОЭЛРО // Энергетика России. 1920-2020 гг. Т. 1. План ГОЭЛРО. М.: ИД ЭНЕРГИЯ, 2006. С. 585-586.

8 План ГОЭЛРО // Энергетика России... С. 610.

${ }^{9}$ План ГОЭЛРО // Энергетика России... С. 611.

${ }^{10}$ План ГОЭЛРО // Энергетика России... С. 615.

${ }^{11}$ План ГОЭЛРО // Энергетика России... С. 547$548,611$.

12 План ГОЭЛРО // Энергетика России... С. 747.

${ }^{13}$ План ГОЭЛРО // Энергетика России... С. 790791.

${ }^{14}$ План ГОЭЛРО // Энергетика России... С. 788, 792-794.

${ }^{15}$ План ГОЭЛРО // Энергетика России... С. 780790.

${ }^{16}$ План ГОЭЛРО // Энергетика России... С. 737.

${ }^{17}$ План ГОЭЛРО // Энергетика России... С. 743.

${ }^{18}$ План ГОЭЛРО // Энергетика России... С. 774, 776.

${ }^{19}$ План ГОЭЛРО // Энергетика России... С. 763, 771.

${ }^{20}$ План ГОЭЛРО // Энергетика России... С. 788.

${ }^{21}$ План ГОЭЛРО // Энергетика России... С. 779.

${ }^{22}$ План ГОЭЛРО // Энергетика России... С. 738.

${ }^{23}$ План ГОЭЛРО // Энергетика России... С. 783.

${ }^{24}$ Из истории СталГРЭС (ВолгоГРЭС). 1926-1953 годы [Электронный ресурс] // Библиотека им. М.А. Шолохова. Блог библиотеки-филиала № 17 им. М.А. Шолохова Волгоградского муниципального учреждения культуры «Централизованная система городских библиотек». URL: http://filial-17.blogspot.com/2016/01/1926-1953. html (дата обращения: 30.11.2020); Ляпинская котельная (Ярославская ГРЭС) [Электронный pecypc]. URL: http://theconstructivistproject. $\mathrm{com} / \mathrm{ru} /$ object/1134/lyapinskaya-kotelnayayaroslavskaya-gres (дата обращения: 01.12.2020); Перечень объектов энергетики
России с 1920 г. по настоящее время // Энергетика России. 1920-2020 гг. Т. 1. План ГОЭЛРО. М.: ИД ЭНЕРГИЯ, 2006. С. 1016, 1017, 1019.

${ }^{25}$ Территориальная принадлежность дается в соответствии с исторической хронологией указанных дат введения в строй объектов энергетики.

${ }^{26}$ Гуртуев Р.С. Проект строительства БаксанГЭС в контексте уточнения плана ГОЭЛРО в 19251927 гг. // Кавказология. 2020. № 1. С. 125126 [Электронный ресурс]. URL: file:///C:/ Users/\%D0\%9A\%D0\%B0\%D1\%82\%D1\%8F/ Downloads/gurtuev_kavkazologija_2020_1.pdf (дата обращения: 02.12.2020).

${ }^{27}$ Портнягин О. За первой дизельной - и ГЭС, и ТЭЦ // Кто есть кто в Сызрани: Справэнциклопедич. изд. / Ред.-сост. Е. Мочалова. Самара: Навигатор, 2001. 328 с. [Электронный ресурc]. URL: http://www.lib.syzran.ru/ personaliy/texty_kto/gorodok.htm\#gas (дата обращения: 13.11.2020).

${ }^{28}$ Очерки истории Волгоградской областной организации КПСС / 2-е изд., перераб. и доп. Волгоград: Ниж.-Волж. кн. изд-во, 1985. С. 219.

${ }^{29}$ «Из истории Костромской теплоэлектроцентрали (ТЭЦ-1) (к 80-летию со дня образования)» // Официальный сайт Областного государственного учреждения «Государственный архив новейшей истории Костромской области» [Электронный ресурc]. URL: https://ganiko.org/ index.htm?vfoto/vyst_foto_06092010/20100906. $\mathrm{htm}$ (дата обращения: 13.11.2020).

${ }^{30}$ Бурдин Е.А. Указ соч. С. 13; Постановление СНК СССР, ЦК ВКП(б) от 14.09.1935 N 2074 «О строительстве гидроузлов в районе Углича и Рыбинска» // КонсультантПлюс [Электронный pecypc]. URL: http://www.consultant. $\mathrm{ru} / \mathrm{cons} / \mathrm{cgi} /$ online.cgi? req=doc $\&$ base $=\mathrm{ESU}$ $\& \mathrm{n}=30716 \# 009226355398713504$ (дата обращения: 25.11.2020).

${ }^{31}$ Носкова О.Л., Розенберг Г.С. Указ. соч. С. 223.

${ }^{32}$ Громов В.И. Самарские энергетические истории. Самара: ООО «Самарский дом печати», 2010. С. 54; Климочкина А.Ю., Курятников В.Н., Малиновская Ю.А. Сланцевый проект Самарского края: достижения и просчеты // Наука и техника. 2018. № 4. С. 21; Перечень объектов энергетики России с 1920 г. по настоящее время // Энергетика России... С. 1015, 1017, 1019, 1021; Халиулин P.P. Развитие генерирующих мощностей электросетевого хозяйства. Первенец энергетики Татарстана // Энергетика Татарстана. 2006. № 4. С. 52.

${ }^{33}$ Воейков Е.В. Указ. соч. С. 81.

${ }^{34}$ План ГОЭЛРО // Энергетика России... С. 753. 
${ }^{35}$ Наша Саратовская губерния, или как Петя путешествовал по г. Саратову и что он узнал о Саратовской губернии / Сост. И. Лельков. Саратов: Паровая Типолитография С.М. Панина, 1915. С. 58.

${ }^{36}$ Путеводитель по г. Саратову с 2 планами в красках и сведения о губернии / Сост. А.Я. Майзульс. Саратов: Типография Т-ва «Сотрудник Школы», 1917. С. 4.

${ }^{37}$ Климочкина А.Ю. Повседневная жизнь... С. 19; Чолахян В.А. Жилищные условия... С. 70.

${ }^{38}$ Самарский трамвай // Самаратранс.info. Общественный транспорт Самарской области. Официальный сайт [Электронный ресурс]. URL: http://www.samaratrans.info/wiki/index. php/Самара_трамвай_история (дата обращения: 20.11.2020).

${ }^{39}$ Балашов - уездный город (1780-1928 гг.). Кн. 1 / Авт.-сост. Л.Н. Масленникова, С.В. Вахрушев, В.В. Смотров. Балашов: «Издатель», 1997. С. 42; Henoчатых B. Строка Руси Великой. К истории Хвалынска // Хвалынск. Портрет города. Краеведческие очерки. М.: Прогресс-Плеяда, 2001. С. 208.

40 Лукошкина Н.Н. Городец в 20-30-е годы XX века // Городецкий край в записках краеведов. Выпуск первый. Городец, 2014 [Электронный pecypc]. URL: http://radilov.ru/krayrodnoy/1338gorodets-v20-30-gody-xxv.html (дата обращения: 10.112020 ).

${ }^{41}$ Погорелов И. Как в наши дни вошел водопровод // Саратовская панорама. 2010. 29 сентября - 5 октября. С. 7; Семенова Е.Ю. Городское пространство российской провинции в годы Первой мировой войны: некоторые аспекты коммуникационно-хозяйственной части // Известия Самарского научного центра РАН. T. 17. № 3 (2). С. 388-398.

${ }^{42}$ Погорелов И. Указ. соч.; Чолахян В.А. Жилищные условия... С. 69.

${ }^{43}$ Косенкова Н.А., Серова А.А. Формирование идентичности общественных объектов на примере Самары // Градостроительство и архитектура. 2018. Т. 8. № 1. С. 111, 115.

${ }^{44}$ Годы и события. Хроника (к 150-летию Самарской губернии: в 2 т. Т. 2. 1921-2000 гг. / Сост.: В.М. Гришина, К.А. Катренко, К.Ф. Нефедова, Р.Ф. Пантюхина, А.Г. Удинцев, Г.С. Яшников. Самара: [б.и.], 2000. С. 44.

${ }^{45}$ Грандиозный проект века // 75 лет ОАО «Татэнерго» [Электронный ресурс]. URL: http:// www.75.tatenergo.ru/75/history1920_1930.html (дата обращения: 10.11.2020).

\title{
RUSSIAN ELECTRIFICATION PLAN AS A FACTOR OF TRANSFORMATION OF THE VOLGA CITY SPACE
}

\author{
(c) 2020 E.Yu. Semenova

\begin{abstract}
Samara Federal Research Center of the Russian Academy of Sciences, Samara State Technical University
\end{abstract}

\begin{abstract}
The article examines the possibility of changing the urban space in connection with the prospects for implementing the GOELRO plan. The components of the GOELRO plan for Volga cities that involve changes in the sphere of communications and development are identified. The influence of the plan on the prospects for the development of urban space in the Volga cities is compared.

Keywords: electrification plan, the Volga region, urban space.
\end{abstract}

DOI: $10.37313 / 2658-4816-2020-2-4-93-101$

Ekaterina Semenova, Doctor of History, Associate Professor, Senior Researcher Fellow, History and Archeology Department, Samara Federal Research Center, Professor, Department of Philosophy and Social and Humanities, Samara State Technical University.E-mail: dashka129k@yandex.ru 